\title{
A political economy of African regionalisms: introduction
}

\section{THE URGENCY OF STUDYING AFRICAN REGIONALISM}

Recent accounts of 'Africa Rising', as well as older claims that the twentyfirst century would be an 'African Century' ${ }^{1}$ have undeniably led to greater attention to the economic and political potential of countries on the African continent. Ever since the adoption, in 1991, of the so-called Abuja Treaty on the establishment of an African Economic Community by the heads of state and government assembled in the Organization of African Unity (OAU), regional economic collaboration has been an integral part of the African political agenda. The Abuja Treaty adopted a stepwise approach to the creation of the African Economic Community, which should be in place by 2025 (Organization of African Unity 1991: art. 6). Despite the treaty's grand intentions, most of the six 'stages' described in the agreement have not been reached.

In March 2018, almost 27 years after the adoption of the Abuja Treaty, 47 African countries were signatories to the Kigali Declaration for the Launch of the African Continental Free Trade Area (AfCFTA), while 44 signed the AfCFTA agreement. The latter specified as its first objective the creation of 'a single market for goods, services, facilitated by movement of persons in order to deepen the economic integration of the African continent and in accordance with the Pan African Vision of "An integrated, prosperous and peaceful Africa" enshrined in Agenda 2063' (African Union 2018a: art. 3a). The 'reiteration' of the 'solemn resolve to deepen our integration through the African Continental Free Trade Area (AfCFTA)' in the Kigali Declaration (African Union 2018c: Preamble) brings to mind many earlier attempts to kick-start economic integration on the continent.

The Kigali Declaration would seem to be easy prey for critics, who could echo Jeffrey Herbst's (2007: 129) scepticism that the history of regional cooperation in Africa is 'a veritable organizational junkyard of unsuccessful attempts to reduce the continent's balkanization [sic]'. We do not rank ourselves among the sceptics à la Herbst, since we recognize that many 
steps have been made on the road towards greater intra-regional cooperation in Africa. At the same time, we feel the need to provide a critical and sober analysis of the current state and prospects of regionalism in Africa, certainly when looking back at earlier accounts that had high expectations and assumed a great potential for regional cooperation as an instrument for achieving greater self-reliance of the continent (Asante 1997: 138-168). In particular, in this book we wish to draw attention to the asymmetries underlying the African regionalist projects, and to analyse how those asymmetries are reflected in the architecture and outcomes of the various regionalisms on the continent.

We do not apply a European yardstick to measure the advance of African regionalism. The European Union's history of regional cooperation is certainly important to the study of regionalism, but it would be a mistake to take this history as an example for regionalisms elsewhere. Having said this, we realize full well that the very rhetoric of politicians in other parts of the world as well as the institutional isomorphism of regionalist frameworks, not least in Africa, have created the impression that institutions have been modelled on the European experience.

The rise of what is termed 'comparative regionalism' has been a counterweight to the eurocentrism of much scholarship on regionalism (Söderbaum 2016b: 7-10). As such, comparative regionalism recognizes that the European history of regional cooperation is not the only experience that counts (see Acharya and Johnston 2007: 6; Warleigh-Lack and Van Langenhove 2010: 545-546; Mattheis 2017: 478; Söderbaum 2016a: 32). Fredrik Söderbaum, one of the most astute analysts of contemporary regionalism, has indicated that:

more than six decades of academic debate has failed to generate satisfactory answers to questions about the origins, logic and consequences of regionalism. Regionalism means different things to different people in different contexts and time periods and, for some observers, regionalism may not mean much at all. There are also fundamental disagreements regarding how regionalism should be studied and compared, not least over whether regionalisms in different parts of the world are unique and discrete phenomena, or part of a broader and more universal logic. (Söderbaum 2016b: 1)

This book is an attempt to study African regionalisms in their own right. We do this by placing the African experience with regionalism in a historical perspective and by paying attention to the specifics of African political and economic development and to the consequences deriving from the insertion of African countries into the global political economy. In order to do so, we focus on five Regional Economic Communities (RECs) in Sub-Saharan Africa: the East African Community (EAC), the 
Economic Community of Central African States (ECCAS), the Economic Community of West African States (ECOWAS), the Intergovernmental Authority on Development (IGAD) and the Southern African Development Community (SADC). ${ }^{2} \mathrm{~A}$ list of the member states of the RECs is given in Table IA. 1 in the Appendix to this introduction. ${ }^{3}$

While our focus is on regionalism in Africa, we are inspired by the insights of comparative regionalism to analyse how the African experience compares to trends and logics that are visible elsewhere. In this sense, we take a lead from Daniel Bach, one of today's leading scholars on the study of regionalism in Africa, who argued that '[t]he study of African regionalisms represents a challenge and an incentive to revisit a number of common assumptions. The notion of "waves" of regionalism and the narratives associated with these is a first issue that calls for reassessment' (Bach 2016b: 7). Although this book does not study the differences between African and other regional schemes, our approach is implicitly comparative, because we apply concepts and approaches derived from the literature on comparative regionalism. In this way, our findings about African regionalism may inform and contribute to broader debates about the nature and development of contemporary regionalism.

\section{MULTIPLE ASYMMETRIES}

In this book, we analyse African regionalisms through the lens of economic and political asymmetries. Asymmetries are a defining feature of Africa's political economy, and we argue that African regionalisms are impacted upon by multiple asymmetries. In this section, we provide an overview of the most significant asymmetries, operating at different levels. First, we discuss asymmetries operating at the level of the international system, which have a structural character. Next, we describe some asymmetries that exist at the continental and sub-regional level, which are characteristic of the interactions among African regions and countries.

\section{Systemic Asymmetries}

The rhetoric of 'Africa Rising', which we referred to at the beginning of this introductory chapter, has spurred considerable debate about the premises underlying the expectations of growth and development in the continent. Various analysts of African regionalism are positive about the potential benefits that countries may derive from the exploitation of natural resources. This positive attitude is reflected in a recent analysis of regional development in Africa, which argued that extractive resources, 
currently the prime revenue earners for African countries, 'have the potential to advance structural transformation and economic development' (Hanson and Tang 2016: 35). This analysis expects that such development may lead to increased interdependence within Africa and will ultimately strengthen the competitiveness of African producers in the world market. Echoing the United Nations Conference on Trade and Development's report (UNCTAD 2013) on private sector dynamism in Africa, a range of authors have emphasized the change to so-called 'developmental regionalism' (for example, Asante 2016: 136; Puplampu 2016: 50-55). Developmental regionalism would involve greater emphasis on the role of the private sector, going beyond the liberalization of trade, and including the promotion of foreign investment, the development of regional industries and the strengthening of regional infrastructure.

The 'Africa Rising' discourse has been challenged by a range of scholars who are inspired by more structural analyses of international political economy. Such analyses point to the sources of the continuation, or even the exacerbation, of systemic asymmetries between Africa and other regions in the world economy. In a recent analysis of industrial development in the global South, economist Dani Rodrik (2016: 2) pointed out that many developing countries are experiencing 'premature deindustrialization', which means they are 'turning into service economies without having gone through a proper experience of industrialization'. According to Rodrik (2016: 4), the main cause of deindustrialization in the developing world lies in trade and globalization, which have hit start-up industries disproportionally because they proved insufficiently competitive in comparison with industries from the global North.

Many analysts have further emphasized the persistence of relations of dependency between Africa and the industrialized countries. The late Samir Amin (2014: 29), one of the prime representatives of African dependency theory, analysed the political economy of contemporary Africa in terms of the lack of inward-looking, or 'auto-centred' development. As a consequence of this, African countries have remained passive players in the world economy, failing to build up their own productive capacity:

While a number of countries in Asia and Latin America did embark during those 'decades of development' of the second half of the twentieth century on a process of industrialisation which turned out, in some cases, to be competitive on global markets, 'successful development' (in fact growth without development) remained in Africa within the old division of labour, i.e. providing raw materials. (Amin 2014: 34)

The lack of structural transformation of Africa's economies is emphasized as well in Addison's (2017) analysis of three decades in Africa's 
development. He notes that the continent's dependence on primary commodity exports has increased over the last 30 years, and that there has not only been little diversification in the manufacturing sector, but also a relative neglect of agriculture; an outcome that is particularly detrimental for the rural poor (Addison 2017: 131-135). This conclusion is mirrored in Taylor's critique of the 'growth hymn' that is part of the 'Africa Rising' discourse. According to Taylor (2016: 14-16), the focus of this discourse on economic growth, measured as an increase of gross domestic product (GDP), obscures the impact that continued natural resource dependence exerts on African economies. Taylor argues that the persistence of deficits in the current account of African countries, as well as their negative genuine savings rates, reveal the shallowness of the analyses of Africa's development, as these do not pay sufficient attention to the downsides of the continent's resource dependence.

The increasing importance of the so-called 'emerging economies' (such as China, India and Brazil) in the world economy does not seem to have had much impact on the one-sidedness of Africa's development pattern, despite all the rhetoric of 'South-South cooperation'. Various analysts have shown that the economic relationships between African countries and the emerging economies have reproduced the continent's dependence on a limited range of natural resources rather than led to economic diversification (Geda et al. 2013; Hout and Warmerdam 2013; Mason 2017). On the basis of an analysis of export specialization patterns of African countries, Geda et al. (2013: 134) concluded that the growth of Chinese demand for commodities has led to the increased specialization of African countries in primary commodity production. Likewise, Hout and Warmerdam (2013: 2-3) demonstrated that the intensification of trade and investment relations between Africa and a range of emerging economies (China, India and Brazil) between 2000 and 2012 has largely reinforced existing production patterns, oriented to raw materials, fuels, ores and minerals. Mason's (2017: 91) study of China's economic, diplomatic and security strategies arrived at the conclusion that African countries run great risks of being locked into a dependent position.

\section{Continental and Sub-regional Asymmetries}

Next to systemic asymmetries, important continental and sub-regional asymmetries should be taken into account when analysing regionalism in Africa. Power asymmetries at the continental or sub-regional level are of central concern to many analysts, and these are often studied through applying the concept of 'hegemony'. Hegemony - or power preponderance - is supposed to impact on a range of outcomes, related to trade, diplomacy 
or security, because of the influence that regional hegemons are supposed to have on the outcome of processes and relationships in their region or on the continent more broadly.

In a theoretical analysis of 'hierarchical regional orders', Garzón Pereira (2014) has argued that asymmetries in power among states in a region have a significant impact on the interactions on a range of issues. In particular, he posits that:

the bulk of transactional bargains (be they consensual, coercive or mixed) between a regional (great) power and its weaker regional neighbors are likely to revolve around three main issues of contention, namely: policy convergence, the transfer of material resources, and the nature of the regional institutions that manage the use and mobilization of the regional power resources. (Garzón Pereira 2014: S33)

In the context of African regionalism, some of the main issues related to the shaping of Regional Economic Communities can be understood with the help of Garzón Pereira's framework. An important point in many African sub-regions is the extent to which decision-making authority is transferred to the RECs. Most states cling to their sovereignty and are quite reluctant to delegate authority to the regional organizations. Further, bargaining in the RECs is often related to the depth of integration, in particular the question whether integration should stop at the establishment of a free trade area or should target more profound, 'behind-the-border' barriers as well. Finally, and in connection with the foregoing points, member states of the RECs are often concerned about the distribution of the benefits of integration, because industries in certain countries are more competitive than in others. This implies that negotiators tend to be concerned about the unequal distribution of benefits, and that the failure to agree on a possible transfer of resources to compensate for the expected inequalities hinders progress on the regionalist agenda.

Regional hegemony in Africa does not necessarily appear conducive to cooperation at the sub-regional level. In relation to this, Arthur (2016: 72-74) has pointed out the roles that South Africa and Nigeria play in their respective regions. He ascribed the decision by Zimbabwe to become part of the Economic Partnership Agreement with the Common Market for Eastern and Southern Africa (COMESA), combined with its membership of SADC, to the country's fear of South African economic dominance. Likewise, according to Arthur (2016: 74), the reluctance on the part of ECOWAS member states to pursue further trade liberalization within the region can be interpreted as a response to Nigeria's dominance of the regional financial and security infrastructure. What is more, both hegemons do not appear to have the ambition to play a leadership role 
beyond their own domain. Fioramonti and Mattheis (2015: 685) have analysed leadership in Africa in terms of 'reluctant hegemony'. In their view, '[b]oth South Africa and Nigeria, the continent's largest economies, have refrained from playing the role of "co-operative hegemon" traditionally associated with Germany or France' (Fioramonti and Mattheis 2015: 681; cf. Adebajo 2008; Hancock 2014).

In this context, economic analyses of the trade-generating potential of regionalist frameworks in Africa have generally tended to be sceptical about the opportunity for sub-regions to achieve greater economic selfreliance. Analysts have emphasized the low potential for trade creation among African countries, because those countries have highly similar production structures. In situations of limited diversification of production, the establishment of free trade areas will likely lead to trade diversion rather than trade creation, because products from 'regional hegemons' (such as Kenya in East Africa, and South Africa in the southern part of the continent) will drive out goods supplied by less competitive producers. This makes it likely that regional asymmetries will be reproduced instead of countered (Cadot et al. 1999: 216).

The recent establishment of Economic Partnership Agreements (EPAs) across Africa, which has been spurred by the desire to secure market access of African economies to the European Union, may turn out to be an additional factor contributing to the limited potential of African trade regionalism. The choices of RECs' member states to align with particular European Union (EU)-induced EPAs, which do not coincide with the RECs, have led to a fragmentation of established regional frameworks rather than a strengthening of regional integration along existing lines (Tavares and Tang 2013: 226). Bach (2016a: 80) has called the EPA negotiations a 'stress test' for the RECs. In his view, the fragmentation that was caused by the establishment of EPAs demonstrated '[t]he negative effects of decades of procrastination over rationalizing and harmonizing the African "spaghetti bowl"' of overlapping regional arrangements (Bach 2016a: 80).

Recent attempts by the African Union (AU) to unify the African position in the so-called 'post-Cotonou' or post-2020 discussion with the European Union (see also Chapter 6) seem to be informed by concerns over the negative impacts of asymmetry and fragmentation, which are due to the existence of eight RECs with overlapping membership and the existence of a host of bilateral agreements with the EU (Carbone 2018: 482-483). The African Union is endeavouring to position itself as the key interlocutor with the European Union in the debate about the future of trade, peace and security and development after the end of the Cotonou Agreement in 2020. The African Common Position for Negotiations of a New Agreement of Cooperation with the European Union (African 
Union 2018d) expresses a preference for a continent-to-continent (and AU-to-EU) relationship and, hence, would lead to the demise of the ACP (that is, Africa, Caribbean and Pacific) Group of States. This common position is perceived by some as a step forward to a stronger African negotiating position vis-à-vis the European Union, and hence as an approach to counter existing asymmetries (for example, Diatta 2018). Yet, others have pointed at the risks involved in breaking the unity of the group of African, Caribbean and Pacific countries, because this may give the EU the opportunity to play one group of developing countries against others by adopting a new divide-and-rule approach (EPA Monitoring 2018).

\section{PLAN OF THE BOOK}

Starting from the notion of multiple asymmetries, this book focuses on processes of regionalism in Africa. In particular, we aim to understand how regionalisms are shaped by asymmetrical relations among African countries, as well as how asymmetries in development are reinforced by regional interactions, and how they are impacted upon by continuing and new external influences.

Chapter 1 provides an overview of the literature on comparative regionalism, in particular the scholarship on African regionalisms. Its aim is to discuss the way in which scholarship on comparative regionalism may contribute to an understanding of the drivers of and actors in regionalism and their impact on asymmetrical development in Africa. The drivers of regionalism are grouped into four categories: material, ideational, political and external. With regard to the actors in regionalism, the chapter identifies states, domestic actors and individual action.

Chapter 2 discusses the origins and post-colonial history of African regionalisms, going back to the establishment of the Organization of African Unity, and tracing the evolution of the African Union. The chapter explores the architecture of African regional institutions, particularly the Regional Economic Communities, as the building blocks for African unity, regional integration and peace and security. The proposed establishment of the African Economic Community in the 1990s is discussed, as this offers insights into the process of consolidating the Regional Economic Communities. The final sections of the chapter emphasize that issues of peace and security, and governance and democracy, play an important role both at the continental level, mainly in relation to the African Union, and at the regional level for the RECs.

Chapter 3 focuses on the regional socio-economic asymmetries characterizing African development. It analyses economic growth over time, 
measured by an increase of GDP and per capita GDP, and human development, expressed as improvements in the human condition (education, health and life expectancy). Further, the chapter discusses the differences among countries and RECs in terms of their populations and their endowments of land and natural resources. We assess how asymmetries among and within RECs relate to the economic position of member states, and how those asymmetries are expressed in the achievements on the human development index and the incidence of multidimensional poverty.

In Chapter 4, we concentrate on the political dimensions of African regionalisms. We describe the consequences of violent conflicts on the African continent, reflected in casualties and mass population displacement, and discuss the conflict prevention and peace-keeping mechanisms that have been set up by the African Union and the Regional Economic Communities. The chapter indicates how conflicts have contributed to asymmetries, because the control of the means of intervention is monopolized by certain African states, and some of them derive moral superiority from their ability to impose sanctions, intervene or threaten with intervention. Finally, the chapter discusses the relationships between conflict incidence, peacefulness and democracy on the one hand, and regional integration on the other.

Chapter 5 contains an analysis of intra-African trade patterns and confronts the aspirations of the African trade agenda with the realities of contemporary intra-regional and intra-African trade. We discuss the aims of African regionalisms, which have been focused on strengthening the economic position of African economies and making the countries, regions and the continent more self-reliant by contributing to economic transformation and diversification. The chapter outlines how the aspirations concerning intra-African trade led to the adoption of the Abuja Treaty on the African Economic Community in 1991, and 27 years later have resulted in the signing of the Agreement Establishing the African Continental Free Trade Area (AfCFTA). In order to confront the aspirations with the realities of trade dynamics, we present data on the development of intra-regional and intra-African trade in manufactured goods. The final section of the chapter looks at the possible future of the RECs within the continental free trade area.

Chapter 6 turns to the relations between Africa, in particular the RECs, and the rest of the world. The first part of the chapter focuses on the long-standing political ties between Africa and the West, and describes the budding relationship between some of the BRICS (Brazil, Russia, India, China and South Africa) and Africa. Next, we discuss the asymmetries in trade relations between the African RECs and their most important partners, notably the European Union and the United States, 
and compare these to the patterns that are emerging in relations with the BRICS countries. Further, we analyse the financial relations of the continent, in particular expressed in investment patterns, by paying attention to traditional investors, but explicitly also looking at the investments flowing from China to Africa. Special attention is given to trends in aid relationships: our analysis again compares the traditional donors with the new players on the geopolitical scene. The chapter concludes by summarizing the relationship between Africa and the rest of the world in terms of profound systemic asymmetries across political, trade, investment and aid relations.

The concluding chapter wraps up the book by reflecting on the aspirations and realities of African regionalisms, as well as the asymmetries involved. The Conclusion emphasizes that continent-wide and regional forms of cooperation have represented small steps toward regional integration. African regionalisms, however, remain subject to substantial power asymmetries among African states, with some of them actually being hegemonic within their own region. At the same time, it is argued that the smaller countries can derive protection from the institutional provisions governing the regional frameworks. The Conclusion pays attention to external asymmetries, particularly visible in the relationships between African countries and regional organizations and China. It finishes with a short reflection on the future of African regionalisms, in particular the steps towards establishing the AfCFTA.

\section{NOTES}

1. 'Africa Rising' was the title of a conference organized by the International Monetary Fund in Mozambique in 2014 (see http://www.africa-rising.org), while the term 'African Century' was used, among others, by former South African President Thabo Mbeki in his acceptance speech of June 1999 (see http://news.bbc.co.uk/2/hi/world/monitoring/360349. stm).

2. Next to these five RECs, the United Nations Economic Commission for Africa (UNECA) has recognized three others: CEN-SAD (the Community of Sahel-Saharan States), COMESA (the Common Market for Eastern and Southern Africa) and UMA (the Arab Maghreb Union). The eight RECs show considerable overlap in membership. Table IA. 1 in the Appendix shows that, of all 55 countries on the continent, only 14 belong to just one regional community. The majority (30 countries) belong to two RECs, and a sizeable number (ten countries) are even members of three communities. The Sahrawi Arab Democratic Republic is the only country that does not belong to any REC, because of the dispute with Morocco over its sovereignty.

In the following chapters, we have not included CEN-SAD because its membership overlaps significantly with ECCAS, ECOWAS and IGAD. COMESA is excluded because of the strong overlap with EAC, ECCAS, IGAD and SADC. We have not included UMA because this book is focused on Sub-Saharan Africa and UMA is predominantly composed of member states north of the Sahara. 
3. The composition of the Regional Economic Communities has changed over time. In analysing historical data on the RECs in the following chapters, we have taken the membership as of 1 January 2019 as a starting point, as this seems to make the most sense from a methodological perspective. Although this choice does not fully reflect the historical evolution of the RECs, a different approach would have created fluctuations in the data series that would have made comparisons over time impossible. 


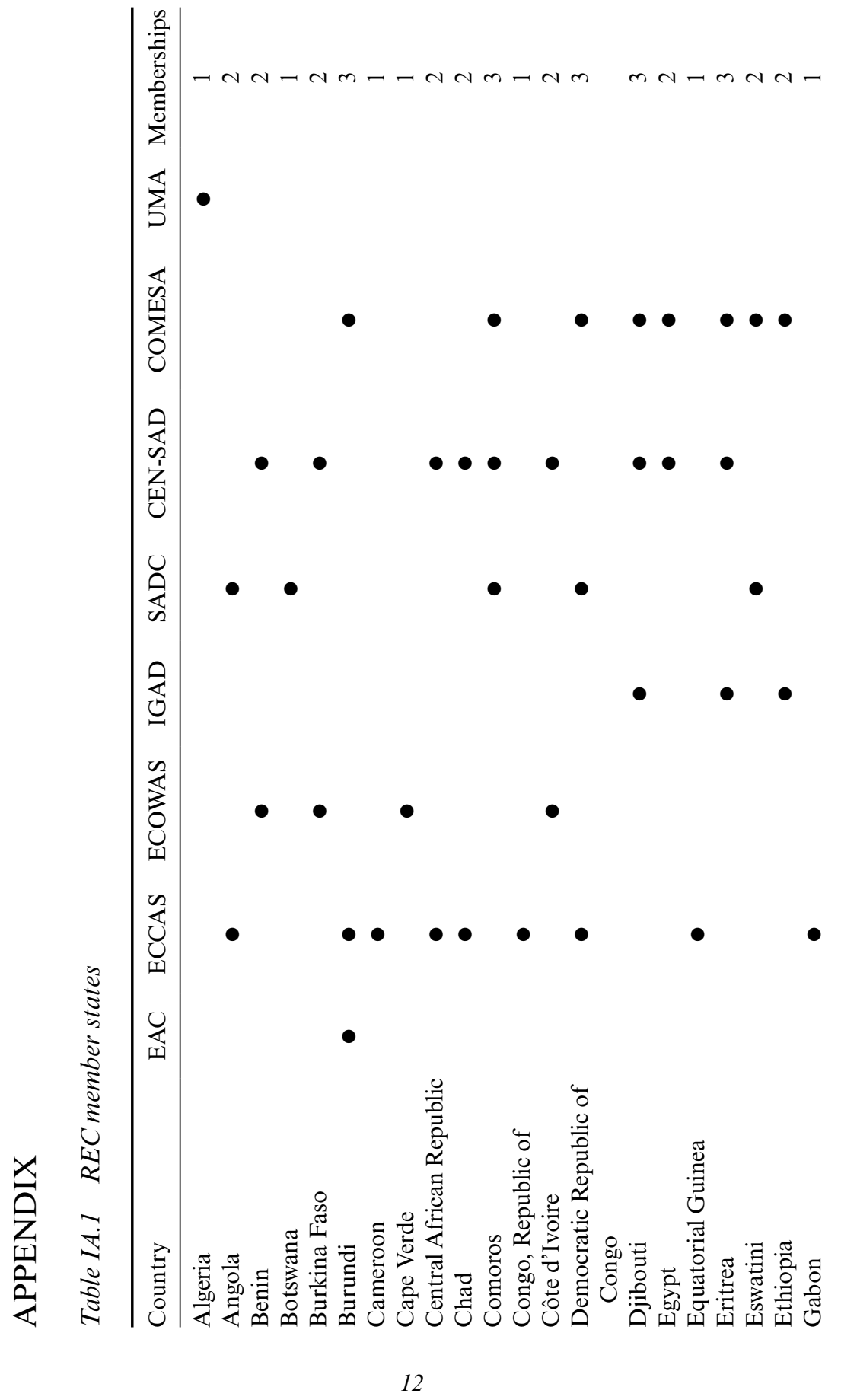




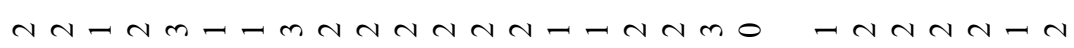

10

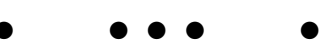

$\bullet \bullet \bullet$

$\bullet$
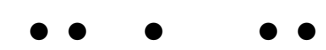

- $\bullet$

$\bullet$

$\bullet \bullet$

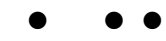

?

- 1
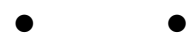

-

-

-

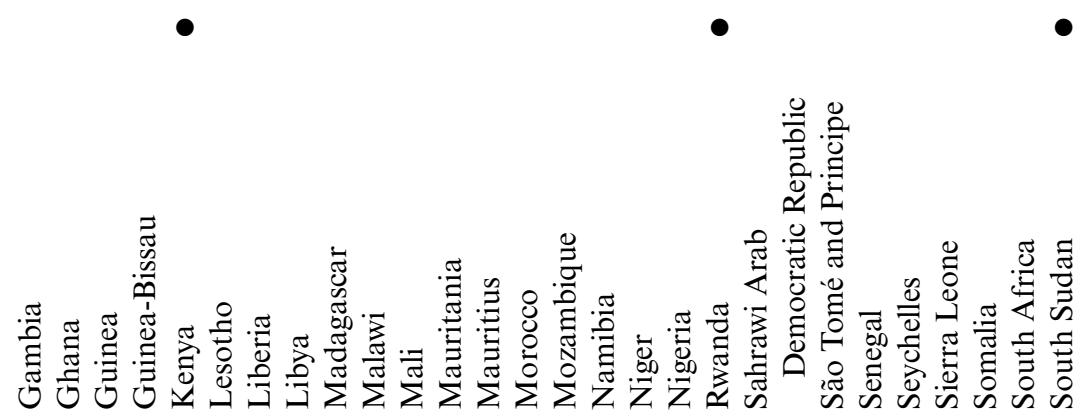




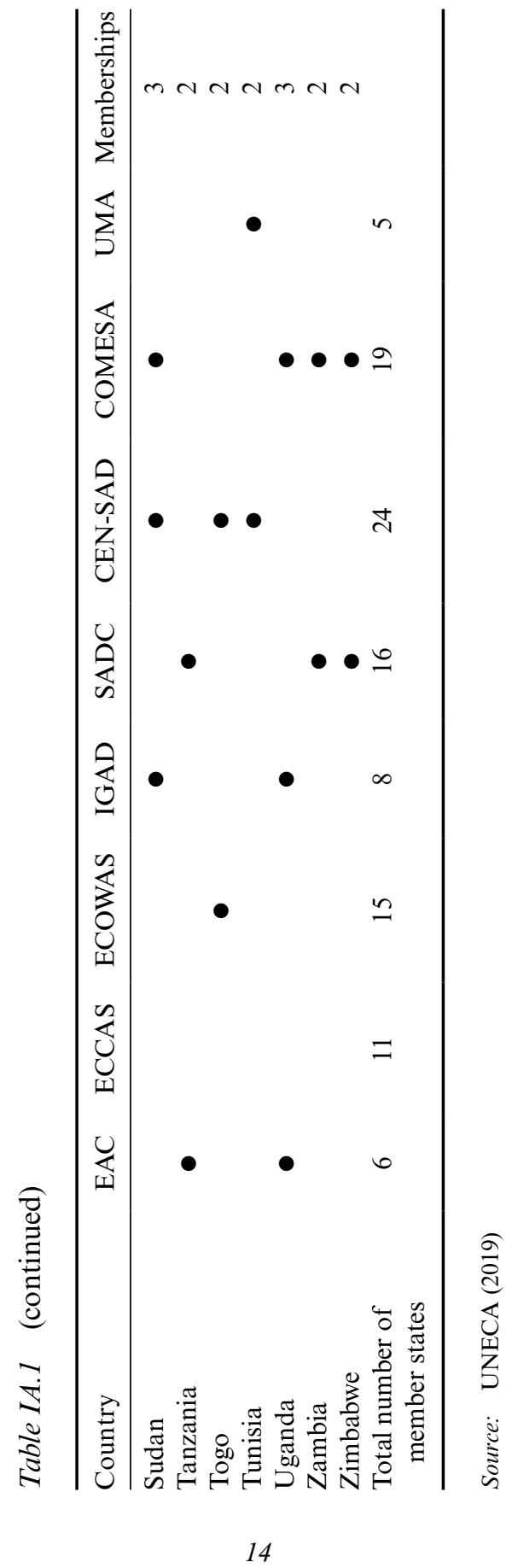

